\title{
THE USE OF FOUR-SQUARE WRITING TO IMPROVE THE WRITING ABILITY OF DESCRIPTIVE TEXTS BY THE FIRST YEAR (X.1) STUDENTS OF SMA NEGERI 4 PEKANBARU
}

\author{
Felci Tria Sauhana \\ English Study Program - Islamic University of Indragiri \\ E-mail: ssauhanafelcitria@gmail.com
}

\begin{abstract}
This research aims to know whether Four-Square Writing Method could improve the students' ability in writing descriptive texts and also the factors that contribute to the improvement. The writer collected the quantitative data by using writing tests and qualitative by using observation sheets and field notes. The minimum criteria of the successful action were 75. Before applying the Four-Square Writing Method, the students were given a pre-test to know their writing ability or their base score. After applying the Four-Square Writing Method, the students' score increased from pre-test to post-test 1 and post-test 2 . Based on the data analysis, the students' score improved from 68,97 in the pre-test, to 72,77 in the post-test 1 and 75,40 in post-test 2. Furthermore, based on the data analysis of students' observation sheet, there is a significant functional improvement of students' activities during teaching and learning process from Cycle $1(58,05 \%)$ to Cycle 2 $(82,18 \%)$. Besides, based on the data analysis of teacher's observation sheet, it also proved that there was a good improvement from teacher's activities in Cycle $1(72,22 \%)$ to Cycle $2(91,67 \%)$. Therefore, the use of Four-Square Writing Method can improve the ability to write descriptive texts by the first year (X.1) students of SMA Negeri 4 Pekanbaru.
\end{abstract}

Keywords: Writing Ability, Descriptive texts, Four-Square Writing Method.

\begin{abstract}
Abstrak
Penelitian ini bertujuan untuk mengetahui apakah metode Four-Square Writing dapat meningkatkan kemampuan peserta didik dalam menulis deskriptif teks, dan juga faktor apa yang berkontribusi terhadap peningkatan tersebut. Peneliti mengumpulkan data kuantitatif dengan menggunakan tes menulis, dan data kualitatif dengan menggunakan lembar observasi dan catatan lapangan. Standar minimum keberhasilan dalam tindakan ini adalah 75. Sebelum menerapkan metode Four-Square Writing, peneliti melakukan pre-tes pada peserta didik untuk mengetahui kemampuan awal mereka. Selanjutnya, setelah menerapkan metode Four-Square Writing, nilai peserta didik mengalami peningkatan dari pre-tes, post-tes 1 dan post-tes 2 . Berdasarkan dari analisa data, nilai peserta didik meningkat dari 68,97 pada pre-tes menjadi 72.77 pada post-tes 1 , dan 75,40 pada post-tes 2 . Kemudian, merujuk pada analisa data lembar observasi peserta didik, terdapat peningkatan yang baik dari aktifitas peserta didik selama dalam proses belajar dan mengajar. Hal ini bisa terlihat dari 58,05\% pada siklus 1 menjadi $82,18 \%$ pada siklus 2 . Selain itu, berdasarkan analisa data dari lembar observasi
\end{abstract}


guru, terdapat juga peningkatan yang baik pada aktifitas guru yakni $72.22 \%$ pada siklus 1 menjadi $91,67 \%$ pada siklus 2 . Oleh karena itu, penggunaan metode Four-Square Writing Method dapat meningkatkan kemampuan menulis peserta didik pada teks deskriptif di kelas X.1 SMA Negeri 4 Pekanbaru.

Kata Kunci: Kemampuan Menulis, Teks Descriptif, Four-Square Writing Method.

\section{INTRODUCTION}

Writing skill has an essential role in learning English. The learners of English as Foreign Language may be able to listen to the music, read some books, or speak in English, but if they cannot produce a written form in English, they are not qualified enough in English in academic purpose. Writing also cannot be separated for other subjects in learning a language since students are often required to complete many assignments in written forms. For example, in reading, speaking or listening classes, students still do writing activity in doing some assignments. Furthermore, an English essay has been one of the very well-known requirements for the application of students' scholarship, study abroad or international research project, and others. The learners of EFL are demanded to have excellent skill in writing.
As the critical skill in English language learning, the improvement of writing ability of the students' needs the individual attention from the teachers, the teachers have to be helpful in order to make the students practice to write continuously because the writing ability needs practice as often as possible.

Based on the curriculum, the Senior High School students are taught and require being able to write a various genre of the text, these types of text are Descriptive, Narrative, Report, Analytical Exposition, Procedure, Recount, Spoof, Anecdote, Discussion, Explanation, Review, Hortatory, and News Items. To enrich knowledge, students have to know and understand the entire genre. They have to know the text purpose, the tenses, the generic structure, the language features, and the kinds. 
As it is mentioned above, the students should be able to express the idea into a short text. Some of the students of the first-year students of SMAN 4 Pekanbaru find that it is difficult to write a text. Through the writer's experience in teaching practice (PPL) in the first year (X.1) students of SMA Negeri 4 Pekanbaru, the writer finds some problems of students writing ability in the classroom. They have low motivation to write and get problem in developing their idea coherently. More than half students $(85 \%$ of the whole students) usually make unnecessary repetition and jumpingoff point in one paragraph with a lot of grammatical errors. The main problem is that only $15 \%$ of students can reach 75 as the Standard Minimum Criteria (KKM).

Based on the result of the interview of some English teachers, the students have so many errors in writing descriptive text so that they cannot reach score 75 as the standard minimum criteria (KKM). In a test of writing descriptive text that the topic given was about "My Friend", it was found that among 29 students, there were only ten students who reached KKM. It means that the students have a problem in writing descriptive text. The first problems of the students in writing descriptive text are many errors in vocabulary, spelling and grammar so that not comprehensible and not organizedanother problem the teachers usually finds that the students are not creative in writing activities. The teachers themselves realize that they also cannot find any suitable method to be applied to engage the students during writing activities, so they choose to teach based on the textbook all the time.

According to some students of SMA Negeri 4 Pekanbaru that has been interviewed by the writer, they told that it is challenging for them to develop their idea in writing descriptive text. They cannot organize their paragraph well and also stuck on the topic. They often confuse to start to write descriptive text because they do not have enough knowledge and interest in the topic. Also, the students do not have space to practice to write, whereas, as it is mentioned before that writing needs 
practice as often as possible. They also said that the way their teacher in teaching is monotonous and makes them dull.

Writing descriptive text is taught by the teacher in order to make the students know how to describe themselves and their surrounding, although it is still in a simple way. Descriptive text is one of text genre which is taught only in first-year students of Senior High School in the second semester. So, the writer realizes that it needs to be taught effectively in order to make students master this text. However, from the information above, many students get difficulties in writing descriptive text because the teacher only explains what the generic structure and the method of how to write the descriptive text, the teachers cannot find any method or new ways to teach the students. Therefore, the students will be unmotivated, bored, and have difficulties in learning descriptive text. They also are not able to recall and to describe the things in a systematic order. Moreover, they cannot describe the parts, qualities, and characteristics of the things completely.

The intense desire for finding the solution to these problems, the use of Four-Square Writing Method is an appropriate way to be applied in the classroom. Based on Gould (1999), Four-Square Writing Method is a simplified graphic organizer for teaching writing to the students. It is a method of teaching necessary writing skills that is applicable across grade levels and curriculum areas. It can be applied for the narrative, descriptive, expository and persuasive forms of writing. Besides, the Four-Square Writing Method is a learning activity to develop and to increase the students' vocabulary knowledge by making a personal connection with words likes in the sentences or paragraph. This method will guarantee that students can write with confidence and fun. FourSquare Writing Method briefly performs the students about the purpose of the genre of the text, the generic structure, and also the language features of the text. It also helps the students in making a paragraph unity and trains them to 
develop their ideas.

Based on the description above, it can be concluded that this method is an appropriate way to be applied in teaching writing a descriptive text of the first-year students of senior high school, because it is suitable across grade levels and curriculum areas, and descriptive text is one of the text genres that could be applied in this method. Another reason is that this method can solve those problems that appear in the first year (X.1) students of SMA Negeri 4 Pekanbaru so that the students can reach 75 as the standard minimum criteria after using this method. Therefore, the writer is interested in researching with the title: The Use of FourSquare Writing Method to Improve the Ability to write Descriptive Texts by the First Year (X.1) Students of SMA Negeri 4 Pekanbaru.

\section{METHOD}

This research was a classroom action research (CAR). The participants of this research were the first year (X.1) students of SMA Negeri 4 Pekanbaru. There are 29 students in this class. The choice of the participants had been considered by the classical problems in writing descriptive text and the appropriateness of the method.

The data collection instruments in this research were writing test (quantitative data), observation sheets and field notes (qualitative data). This research consisted of two cycles (each cycle consists of three meetings). The writer administered a pre-test to find out the students' fundamental score in writing descriptive texts. After it had been accomplished, the writer gave treatment. Then, at the end of each cycle, the writer administrated post-test (one test for each cycle) to find out the improvement of the students' score after the treatments applied.

The implementation of the Four Square Writing Method in teaching writing could be described in the following table: 
Table 1. Steps of Teaching Procedure

\begin{tabular}{|l|l|}
\hline Step & Teaching Procedure \\
\hline First & The teacher asks the students to write the topic in the centre box (the topic has \\
\hline Second & The teacher asks the students to write supporting sentences, which support the \\
\hline Third & The teacher guides the students to add supporting details in each box $(2,3,4)$. \\
\hline Fourth & The teacher asks the students to add vivid language. \\
\hline Fifth & The teacher guides the students to fill box number 5 by the conclusion of the \\
\hline Sixth & The teacher asks the students to add transition words for each box put off the \\
\hline
\end{tabular}

Hughes (2003)

Table 2. The Scoring System of Writing

\begin{tabular}{|c|c|c|}
\hline No. & The Aspects of Writing to be Evaluated & Scores \\
\hline 1 & Grammar & $6: 5: 4: 3: 2: 1$ \\
\hline 2 & Vocabulary & $6: 5: 4: 3: 2: 1$ \\
\hline 3 & Mechanics & $6: 5: 4: 3: 2: 1$ \\
\hline 4 & Fluency & $6: 5: 4: 3: 2: 1$ \\
\hline 5 & Form/organization & $6: 5: 4: 3: 2: 1$ \\
\hline
\end{tabular}

To analyze the quantitative data, the writer used the following formula to analyze the students' writing ability:

Score $=\mathrm{O}+\mathrm{F}+\mathrm{V}+\mathrm{G}+\mathrm{M}$

Where:

$\mathrm{O}=$ ability in organization

$\mathrm{F}=$ ability in fluency

$\mathrm{V}=$ ability in vocabulary

$\mathrm{G}=$ ability in grammar

$\mathrm{M}=$ ability in mechanics

Then, to find out the real score of the students, the writer calculated the scores by using the formula:

$\mathrm{RS}=\frac{\mathrm{TS}}{\mathrm{N}} \times 100$

Where:

$\mathrm{RS}=$ Individual Real score
$\mathrm{TS}=$ Total score of the aspects of writing

$\mathrm{N}=$ Maximum score (30)

\section{Hatch and Farhady (1982)}

Meanwhile, the qualitative data was gathered through the checklist of the observation sheets. To analyze and measure the qualitative data, the writer adapted Gay (2000) technique as follows:

\section{a. Prepare the data}

The writer must make and organization of grouping data. The writer makes a format for the data from the observation sheets.

\section{b. Read the data}

The writer reads and analyzes the data from the observation sheets deeply. 


\section{c. Describes the data}

The writer describes the data that she will get from teaching and learning process in order to complete the information about arranging, participant and activity.

\section{d. Classifying}

The writer must put the data in categorizing it to the aspect of data.

\section{e. Interpreting}

In interpreting the data, the writer has to know the aspects and data connection to make a summary. The next step is writing a report of research in order to explain the research.

\section{FINDING AND DISCUSSION}

In order to get the data on the students' score of their ability in writing descriptive texts, the writer collected the data by giving tests (pre-test, post-test 1 and post-test 2).

$$
\text { Before conducting the }
$$
treatment, the writer gave a pre-test to the students.

It was done to know the writing ability of the students before the treatment given. The writer asked three raters to evaluate the students' writing. The writer calculated their percentages in order to know whether they could reach 75 as the standard minimum criteria (KKM) or not. The result of each rater was combined and then divided by three. The data was computed and shown in the following table:

\section{Table 3 The Students' Pre-Test Score}

\begin{tabular}{|c|c|c|c|}
\hline No & Score & F & \% \\
\hline 1. & $\geq 75$ & 7 & $24.14 \%$ \\
\hline 2. & $<75$ & 22 & $75.86 \%$ \\
\hline \multicolumn{2}{|c|}{ Total } & $\mathbf{2 9}$ & $\mathbf{1 0 0 \%}$ \\
\hline
\end{tabular}

From the table above, it could be concluded that only 7 of 29 students who were able to reach score 75 as Standard Minimum Criteria. It means that only $24.14 \%$ who reached $\geq 75$ and the rest 22 students $(75.86 \%)$ had a score $<75$ before the writer implemented FourSquare Writing Method.

If we saw from the score interpretation for students' achievement (Cohen: 1989), the data could be shown as follows: 
Table 4 The Score Interpretation for Students' Achievement in Pre-Test

\begin{tabular}{|c|c|c|c|c|}
\hline No & Interpretation & Score & $\mathbf{F}$ & $\%$ \\
\hline 1. & Very good & $89-100$ & 0 & 0 \\
\hline 2. & Good & $76-88$ & 7 & 24.14 \\
\hline 3. & Fair & $64-75$ & 15 & 51.72 \\
\hline 4. & Weak & $52-63$ & 7 & 24.14 \\
\hline 5. & Poor & $\leq 51$ & 0 & 0 \\
\hline \multicolumn{3}{|c|}{ Total } & 29 & 100 \\
\hline
\end{tabular}

The writer also presents the data of the students' ability from average score according to five aspects of writing first year (X.1) students of SMA Negeri 4 Pekanbaru in writing descriptive text.

Table 5 The Students' Ability in Each Aspect of Writing in Pre-test

\begin{tabular}{|c|c|c|}
\hline No. & Aspects of Writing & Average \\
\hline 1 & Grammar & 4.14 \\
\hline 2 & Vocabulary & 4.28 \\
\hline 3 & Mechanics & 4.24 \\
\hline 4 & Fluency & 4.18 \\
\hline 5 & Organization & 3.85 \\
\hline
\end{tabular}

As the following table:

1. Grammar was 4.14

2. Vocabulary was 4.28

3. Mechanics was 4.24

4. Fluency was 4.18

5. Organization was 3.85

The lowest aspects were "Organization" and "Grammar". It means the comprehension of the students about "Organization" and "Grammar" still low.

\section{Findings of Post-Test in Cycle 1}

After giving pre-test, the writer then started Cycle 1 and applied the Four Square Writing
Method in order to improve students' writing ability of descriptive text.

The writer then conducted some observation which regarded about teaching and learning process in the classroom. The students and the writer herself observed by Ofilia Yafriani, S.Pd, the English teacher of the first year (X.1) students of SMA Negeri 4 Pekanbaru.

In researching by using FourSquare Writing Method to improve the students' ability in writing descriptive text, the writer found some improvement in their activity in applying it. It is shown by the number of students who followed the 
activity in every meeting of the following table and chart: teaching and learning process in the

Table 6 The Students' Activities in Cycle 1

\begin{tabular}{|l|l|l|l|l|l|l|l|l|r|}
\hline \multirow{2}{*}{ No } & \multirow{2}{*}{ Students' Activities } & \multicolumn{2}{|c|}{ Meeting 1 } & \multicolumn{2}{l|}{ Meeting 2 } & \multicolumn{2}{|c|}{ Meeting 3 } & \multicolumn{2}{|c|}{ Average } \\
\cline { 3 - 10 } & & F & \% & F & \% & F & \% & F & \% \\
\hline 1. & Write the topic sentence & 25 & 86.21 & 26 & 89.66 & 27 & 93.10 & 26 & 89.66 \\
\hline 2. & Write supporting & 15 & 51.72 & 17 & 58.62 & 20 & 68.97 & 17 & 59.77 \\
\hline 3. & Add three supporting & 10 & 34.48 & 12 & 41.38 & 16 & 55.17 & 13 & 43.68 \\
\hline 4. & Add the vivid language & 8 & 27.59 & 13 & 44.83 & 15 & 51.72 & 12 & 41.38 \\
\hline 5. & Write the concluding & 13 & 44,83 & 18 & 62.07 & 20 & 68.97 & 17 & 58.62 \\
\hline 6. & Add the transition words & 12 & 41.38 & 17 & 58.62 & 19 & 65.52 & 16 & 55.17 \\
\hline Average & 14 & 47.70 & 17 & 59.20 & 20 & 67.24 & 17 & 58.05 \\
\hline
\end{tabular}

The table above shows that the students' activities score in Cycle 1 consists of the first, second, and third meeting.

At the $1^{\text {st }}$ meeting, there were 25 students $(86.21 \%)$ could write the topic sentence, 15 students $(51.72 \%)$ could write supporting sentences, ten students $(34.48 \%)$ could add three supporting details, eight students $(27.59 \%)$ could add the vivid language, 13 students $(44.83 \%)$ could write the concluding sentence, and 12 students $(41.38 \%)$ could add the transition words.

At the $2^{\text {nd }}$ meeting, there were 26 students $(89.66 \%)$ could write the topic sentence, 17 students (58.62\%) could write supporting sentences, 12 students $(41.38 \%)$ could add three supporting details, 13 students (44.83\%) could add the vivid language, 18 students (62.07\%) could write the concluding sentence, and 17 students $(58.62 \%)$ could add the transition words.

At the $3^{\text {rd }}$ meeting, there were 27 students $(93.10 \%)$ could write the topic sentence, 20 students $(68.97 \%)$ could write supporting sentences, 16 students $(55.17 \%)$ could add three supporting details, 15 students $(51.72 \%)$ could add the vivid language, 20 students $(68.97 \%)$ could write the concluding sentence, and 19 students $(65.52 \%)$ could add the transition words. The table below shows the learning process in cycle 1: 
Table 7 The Teacher's Activities in Cycle 1

\begin{tabular}{|c|c|c|c|c|c|c|}
\hline No. & Teacher Activities & M1 & M2 & M3 & Total & $\%$ \\
\hline 1. & Greeting to the students. & $\sqrt{ }$ & $\sqrt{ }$ & $\sqrt{ }$ & 2 & 66.7 \\
\hline 2. & Checking the attendance list. & $\sqrt{ }$ & - & $\sqrt{ }$ & 2 & 66.7 \\
\hline 3. & Introduction about the topic (descriptive text). & $\sqrt{ }$ & $\sqrt{ }$ & - & 2 & 66.7 \\
\hline 4. & $\begin{array}{l}\text { Introduction of Four-Square Writing Method } \\
\text { in teaching for topic lesson. }\end{array}$ & $\sqrt{ }$ & - & $\sqrt{ }$ & 2 & 66.7 \\
\hline 5. & $\begin{array}{l}\text { Asking the students to write the topic in the } \\
\text { centre box (the topic has been chosen). }\end{array}$ & $\sqrt{ }$ & $\sqrt{ }$ & - & 2 & 66.7 \\
\hline 6. & $\begin{array}{l}\text { Asking the students to write supporting } \\
\text { sentences, which support the topic in box } 2,3 \text {, } \\
\text { and } 4 \text {. }\end{array}$ & $\sqrt{ }$ & $\sqrt{ }$ & $\sqrt{ }$ & 3 & 100 \\
\hline 7. & $\begin{array}{l}\text { Guiding the students to add supporting details } \\
\text { in each box }(2,3,4) \text {. }\end{array}$ & - & $\sqrt{ }$ & $\sqrt{ }$ & 2 & 66.7 \\
\hline 8. & Asking the students to add the vivid language. & - & $\sqrt{ }$ & $\sqrt{ }$ & 2 & 66.7 \\
\hline 9. & $\begin{array}{l}\text { Guiding the students to fill box number } 5 \text { by } \\
\text { the conclusion of the whole essay which } \\
\text { restates the topic sentence. }\end{array}$ & $\sqrt{ }$ & $\sqrt{ }$ & $\sqrt{ }$ & 3 & 100 \\
\hline 10. & $\begin{array}{l}\text { Asking the students to add transition words for } \\
\text { each boxes put off the essay into the paragraph } \\
\text { form. }\end{array}$ & - & $\sqrt{ }$ & $\sqrt{ }$ & 3 & 100 \\
\hline 11. & Conclusion. & - & - & $\sqrt{ }$ & 1 & 33.3 \\
\hline 12. & Evaluation. & - & $\sqrt{ }$ & $\sqrt{ }$ & 2 & 66.7 \\
\hline Total & & 7 & 9 & 10 & & \\
\hline \multicolumn{2}{|c|}{ Percentage } & 58.3 & 75 & \begin{tabular}{|l|}
83.3 \\
\end{tabular} & & \\
\hline
\end{tabular}

Based on the table above could be seen that the teacher did the activities at the 1 st meeting was 7 $(58.33 \%)$ and the activities which was not done was $5(41.67 \%)$. At the 2nd meeting, the teacher did 9 (75\%) activities and did not do 3 (25\%) activities. At the 3rd meeting, the teacher did $10(83.33 \%)$ activities and did not do 2 (17\%) activities.

\section{Findings of Post-Test in Cycle 1}

The average score in the pretest was 68.97. It means that the students could not reach score 75 as the standard minimum criteria. After conducted the treatment in the first cycle, the writer analyzed that there was increasing of students results in post-test 1 . The students' score is computed, which is shown in the following table:

Table 8 The Students' Post-Test Score in Cycle 1

\begin{tabular}{|c|c|c|c|}
\hline No & Score & $\mathbf{F}$ & $\%$ \\
\hline 1. & $\geq 75$ & 13 & $44.83 \%$ \\
\hline 2. & $<75$ & 16 & $55.17 \%$ \\
\hline \multicolumn{2}{|c|}{ TOTAL } & 29 & $100 \%$ \\
\hline
\end{tabular}


From the table above, it could be concluded that 13 of 29 students who can reach score 75 as Standard Minimum Criteria. It means that $44,83 \%$ who reach $\geq 75$ and the rest 16 students $(55.17 \%)$ had a score < 75 after the writer applied FourSquare Writing Method. In conclusion, the students' post-test writing ability in Cycle 1 by the first year (X.1) students of SMA Negeri 4
Pekanbaru was not satisfied enough, because the students who got score 75 still less than $65 \%$. So, the writer decided to continue the research to Cycle 2 in order to improve the students who got a score under 75 .

If we saw from the score interpretation for students' achievement (Cohen:1989), the data could be shown as follows:

Table 9 The Score Interpretation for Students' Achievement in Post-Test in Cycle 1

\begin{tabular}{|c|c|c|c|c|}
\hline No & Interpretation & Score & $\mathbf{F}$ & $\%$ \\
\hline 1. & Very good & $89-100$ & 0 & $0 \%$ \\
\hline 2. & Good & $76-88$ & 10 & $34.48 \%$ \\
\hline 3. & Fair & $64-75$ & 15 & $51.72 \%$ \\
\hline 4. & Weak & $52-63$ & 4 & $13.79 \%$ \\
\hline 5. & Poor & $\leq 51$ & 0 & $0 \%$ \\
\hline \multicolumn{3}{|c|}{ Total } & 29 & $100 \%$ \\
\hline
\end{tabular}

From the table, we could see that there was an increase in students' writing ability after the writer applying Four-Square Writing Method in teaching and learning process. Based on the table above, there still no students $(0 \%)$ reached level poor and outstanding. Nevertheless, there were ten students
(34.48\%) reached level good, 15 students $(51.72 \%)$ reached level fair, and four students $(13.79 \%)$ reached level weak.

The writer also displayed the improvement of the students' average score in the pre-test to post-test 1 according to five aspects of writing as the following table: 
Table 10 The Students' Ability in Each Aspect of Writing in Pre-Test to PostTest 1

\begin{tabular}{|c|c|c|c|}
\hline \multirow{2}{*}{ No. } & \multirow{2}{*}{ Aspects of Writing } & \multicolumn{2}{|c|}{ Average Score } \\
\cline { 3 - 4 } & & Pre-Test & Post-Test 1 \\
\hline 1 & Grammar & 4.14 & 4.25 \\
\hline 2 & Vocabulary & 4.28 & 4.43 \\
\hline 3 & Mechanics & 4.24 & 4.25 \\
\hline 4 & Fluency & 4.18 & 4.25 \\
\hline 5 & Organization & 3.85 & 4.23 \\
\hline
\end{tabular}

From the table above, the students' ability appraised from scale 1 to 6 , the average score of the students for aspect in pre-test and post-test 1 were:

a. Grammar, from 4.14 to 4.25

b. Vocabulary, from 4.28 to 4.43

c. Mechanics, from 4.24 to 4.25

d. Fluency, from 4.18 to 4.25

e. Organization, from 3.85 to 4.23

It could be defined that the lowest aspect was “Organization". It means that the comprehension of the students about "Organization" still low, even though it had been increased from the result in the pretest. Besides, the aspect of "Grammar" had good improvement.

\section{The Discussion of Cycle 2}

While conducting Cycle 2, the writer began Four-Square Writing Method with six steps that had been executed in Cycle 1. The writer was so satisfied with what she found as in the final result of Cycle 2. Most of the students now had been improved after applying this writing method. It is shown by the students' number who followed the activities of Cycle 2 as in the table and chart below:

Table 11 The Students' Activities in Cycle 2

\begin{tabular}{|c|l|c|c|c|c|c|c|c|c|}
\hline \multirow{2}{*}{ No } & \multirow{2}{*}{ Students' Activities } & \multicolumn{2}{|c|}{ Meeting 1 } & \multicolumn{2}{|c|}{ Meeting 2 } & \multicolumn{2}{c|}{ Meeting 3 } & \multicolumn{2}{c|}{ Average } \\
\cline { 3 - 9 } & & $\mathrm{F}$ & $\%$ & $\mathrm{~F}$ & $\%$ & $\mathrm{~F}$ & $\%$ & $\mathrm{~F}$ & $\%$ \\
\hline 1 & Write the topic sentence & 27 & 93.1 & 28 & 96.5 & 29 & 100 & 28 & 96.5 \\
\hline 2 & $\begin{array}{l}\text { Write supporting } \\
\text { sentences }\end{array}$ & 25 & 86.2 & 27 & 93.1 & 28 & 96.5 & 27 & 91.9 \\
\hline 3 & $\begin{array}{l}\text { Add three supporting } \\
\text { details }\end{array}$ & 20 & 68.9 & 25 & 86.2 & 27 & 93.1 & 24 & 82.7 \\
\hline 4 & Add the vivid language & 17 & 58.6 & 20 & 68.9 & 22 & 75.8 & 20 & 67.8 \\
\hline
\end{tabular}




\begin{tabular}{|c|l|r|c|c|c|c|c|c|c|}
\hline 5 & $\begin{array}{l}\text { Write the concluding } \\
\text { sentence }\end{array}$ & 20 & 68.9 & 23 & 79.3 & 25 & 86.2 & 23 & 78.1 \\
\hline 6 & Add the transition words & 19 & 65.5 & 22 & 75.8 & 25 & 86.2 & 22 & 75.8 \\
\hline & Average & 21 & 73.5 & 24 & 83.3 & 26 & 89.6 & 24 & 82.2 \\
\hline
\end{tabular}

The table above shows that the students' activities score in Cycle 2 consists of the first, second, and third meeting as well as Cycle 1 . At the $1^{\text {st }}$ meeting, there were 27 students $(93,10 \%)$ could write the topic sentence, 25 students $(86,21 \%)$ could write supporting sentences, 20 students $(68,97 \%)$ could add three supporting details, 17 students $(58,62 \%)$ could add the vivid language, 20 students $(68,97 \%)$ could write the concluding sentence, and 19 students $(65,52 \%)$ could add the transition words.

At the $2^{\text {nd }}$ meeting, there were 28 students $(96,55 \%)$ could write the topic sentence, 27 students $(93,10 \%)$ could write supporting sentences, 25 students $(86,21 \%)$ could add three supporting details, 20 students $(68,97 \%)$ could add the vivid language, 23 students $(79,31 \%)$ could write the concluding sentence, and 22 students $(75,86 \%)$ could add the transition words.

At the $3^{\text {rd }}$ meeting, there were 29 students $(100 \%)$ could write the topic sentence, 28 students $(96,55 \%)$ could write supporting sentences, 27 students $(93,10 \%)$ could add three supporting details, 22 students $(75,86 \%)$ could add the vivid language, 25 students $(86,21 \%)$ could write the concluding sentence, and 25 students $(86,21 \%)$ could add the transition words.

From the information above, it could be concluded that there were useful improvements in students' activities during the teaching and learning process in Cycle 2. The writer was also satisfied because the research was a success.

The table below shows the teacher's activities during the teaching and learning process in cycle 2: 
Table 12 The Teacher's Activities in Cycle 2

\begin{tabular}{|c|c|c|c|c|c|c|}
\hline No & Teacher Activities & M1 & M2 & M3 & Total & $\%$ \\
\hline 1 & Greeting to the students. & $\sqrt{ }$ & $\sqrt{ }$ & $\sqrt{ }$ & 3 & 100 \\
\hline 2 & Checks the attendance list. & $\sqrt{ }$ & - & $\sqrt{ }$ & 2 & 66.67 \\
\hline 3 & Introduction about the topic (descriptive & $\sqrt{ }$ & $\sqrt{ }$ & $\sqrt{ }$ & 3 & 100 \\
\hline 4 & $\begin{array}{l}\text { Introduces Four-Square Writing Method in } \\
\text { teaching for topic lesson. }\end{array}$ & $\sqrt{ }$ & $\sqrt{ }$ & $\sqrt{ }$ & 3 & 100 \\
\hline 5 & $\begin{array}{l}\text { Asks the students to write the topic in } \\
\text { the center box (the topic has been }\end{array}$ & $\sqrt{ }$ & $\sqrt{ }$ & $\sqrt{ }$ & 3 & 100 \\
\hline 6 & $\begin{array}{l}\text { Asks the students to write supporting } \\
\text { sentences, which support the topic in } \\
\text { box } 2,3 \text {, and } 4 \text {. }\end{array}$ & $\sqrt{ }$ & $\sqrt{ }$ & $\sqrt{ }$ & 3 & 100 \\
\hline 7 & $\begin{array}{l}\text { Guides the students to add supporting } \\
\text { details in each box }(2,3,4) \text {. }\end{array}$ & $\sqrt{ }$ & $\sqrt{ }$ & $\sqrt{ }$ & 3 & 100 \\
\hline 8 & Asks the students to add the vivid language. & $\sqrt{ }$ & $\sqrt{ }$ & $\sqrt{ }$ & 3 & 100 \\
\hline 9 & $\begin{array}{l}\text { Guides the students to fill box number } 5 \text { by } \\
\text { the conclusion of the whole essay which } \\
\text { restates the topic sentence. }\end{array}$ & $\sqrt{ }$ & $\sqrt{ }$ & $\sqrt{ }$ & 3 & 100 \\
\hline 10 & $\begin{array}{l}\text { Asks the students to add transition words } \\
\text { for each box, put off the essay into the } \\
\text { paragraph form. }\end{array}$ & $\sqrt{ }$ & $\sqrt{ }$ & $\sqrt{ }$ & 3 & 100 \\
\hline 11 & Conclusion. & - & $\sqrt{ }$ & $\sqrt{ }$ & 2 & 66.67 \\
\hline 12 & Evaluation. & - & $\sqrt{ }$ & $\sqrt{ }$ & 2 & 66.67 \\
\hline \multicolumn{2}{|c|}{ Total } & 10 & 11 & 12 & & \\
\hline \multicolumn{2}{|c|}{ Percentage } & 83.3 & 91.7 & 100 & & \\
\hline
\end{tabular}

The table above shows the teacher's activities in Cycle 2 consist of the first, second, and third meetings. Based on the table above could be seen that the teacher did the activities at the $1^{\text {st }}$ meeting was 10 (83.3\%) and the activities which were not done was $2(16.7 \%)$. At the $2^{\text {nd }}$ meeting, the teacher did 11 (91.7\%) activities and did not do 1 (7.3\%) activities. At the $3^{\text {rd }}$ meeting, the teacher did $12(100 \%)$ activities.

\section{Findings of Post-Test in Cycle 2}

After re-conducting FourSquare Writing Method, the writer found significant improvement from the previous cycle to the cycle. Students had been through the test in order to make sure their ability in writing descriptive text.

The test instrument which was used at the end of this cycle was similar to the test instrument, which was used in pre-test and post-test 1 . The students' score is computed, which is shown in the following table: 
Table 13 The Students' Post-Test Score in Cycle 2

\begin{tabular}{|c|c|c|c|}
\hline No & Score & F & \% \\
\hline 1. & $\geq 75$ & 23 & 79.31 \\
\hline 2. & $<75$ & 6 & 20.69 \\
\hline \multicolumn{2}{|c|}{ TOTAL } & 29 & 100 \\
\hline
\end{tabular}

From the table and the chart above, it could be concluded that 23 of 29 students can reach score 75 as Standard Minimum Criteria. It means that $79.31 \%$ who reach $\geq 75$ and the rest six students $(20.69 \%)$ have a score $<75$ after the writer applied Four- Square Writing Method in Cycle 2. In conclusion, the students' post-test writing ability in Cycle 1 by the first year (X.1) students of SMA Negeri 4 Pekanbaru was a success, because the students who got score $\geq 75$ were more than $65 \%$. It means that the use of FourSquare Writing Method to improve the ability to write descriptive texts of the first year (X.1) students of SMA Negeri 4 Pekanbaru was a success.

If we saw from the score interpretation for students' achievement (Cohen:1989), the data could be shown as follows:

Table 14 The Score Interpretation for Students' Achievement in Post-Test in Cycle 2

\begin{tabular}{|c|c|c|c|c|}
\hline No & Interpretation & Score & $\mathbf{F}$ & $\%$ \\
\hline 1. & Very good & $89-100$ & 1 & 3 \\
\hline 2. & Good & $76-88$ & 21 & 72.41 \\
\hline 3. & Fair & $64-75$ & 7 & 24.14 \\
\hline 4. & Weak & $52-63$ & 0 & 0 \\
\hline 5. & Poor & $\leq 51$ & 0 & 0 \\
\hline \multicolumn{3}{|c|}{ TOTAL } & 29 & 100 \\
\hline
\end{tabular}

From the table above, the students' achievement in writing descriptive text shows an increase in the second cycle. There were no students reached poor and weak level. There were seven students (24.14\%) reached fair level, 21 students $(72.41 \%)$ reached good level, and one student (3\%) reached very good level.

The writer also displayed the improvement of the students' average score in the pre-test, post-test 1 to post-test 2 according to five aspects of writing as the following table: 
Table 15 The Students' Ability in Each Aspect of Writing in Pre-Test, PostTest 1 to Post-Test 2

\begin{tabular}{|c|c|c|c|}
\hline \multirow{2}{*}{ Aspects of Writing } & \multicolumn{3}{|c|}{ Average Score } \\
\cline { 2 - 4 } & Pre-Test & Post-Test 1 & Post-Test 2 \\
\hline Grammar & 4.14 & 4.25 & 4.45 \\
\hline Vocabulary & 4.28 & 4.43 & 4.61 \\
\hline Mechanics & 4.24 & 4.25 & 4.48 \\
\hline Fluency & 4.18 & 4.25 & 4.47 \\
\hline Organization & 3.85 & 4.23 & 4.54 \\
\hline
\end{tabular}

From the table and chart above, the students' ability appraised from scale 1 to 6 , the average score of the students for aspect in pre-test and post-test 1 and 2 are:

a. Grammar increase from 4.14 to 4.25 and up again to 4.45

b. Vocabulary increase from 4.28 to 4.43 and up again to 4.61

c. Mechanics increase from 4.24 to 4.25 and up again to 4.48

d. Fluency increase from 4.18 to 4.25 and up again to 4.47

e. Organization increase from 3.85 to 4.23 and up again to 4.54

According to the previous cycle, the aspect of organization now raise in Cycle 2. It means that the comprehension of the students about organization had been improved.

\section{The Discussions of the Findings}

In this discussion, the writer analyzed the result of students' writing improvement. The data analysis consisted of the data compilation from the qualitative data (students' observation sheet and teacher's observation sheet) and the quantitative data (pre-test, post-test 1 , and post-test 2).

The improvement of students' activities in writing descriptive texts can be seen as the following table:

Table 16 The Improvement of Students' Activities in Writing Descriptive Texts

\begin{tabular}{|c|c|c|c|}
\hline \multirow{2}{*}{ No } & \multirow{2}{*}{ Cycle } & \multicolumn{2}{|c|}{ Students Activities } \\
\cline { 3 - 4 } & & $\mathbf{F}$ & \% \\
\hline 1. & Cycle 1 & 17 & $58.05 \%$ \\
\hline 2. & Cycle 2 & 24 & $82.18 \%$ \\
\hline
\end{tabular}


Based on the table and chart above, it can be seen that the improvement of the students' activities from $58.05 \%$ in Cycle 1 to $82.18 \%$ in Cycle 2. So, it could be concluded that there were good improvements in students' activities during the teaching and learning process from Cycle 1 to Cycle 2.

Besides, the improvement of teacher's activities can be seen on the following table:

\section{Table 17 The Improvement of Teacher's Activities}

\begin{tabular}{|c|c|c|c|}
\hline \multirow{2}{*}{ No. } & \multirow{2}{*}{ Cycle } & \multicolumn{2}{|c|}{ Teacher Activities } \\
\cline { 3 - 4 } & & $\mathbf{F}$ & $\%$ \\
\hline 1. & Cycle 1 & 9 & $72.22 \%$ \\
\hline 2. & Cycle 2 & 11 & $91.67 \%$ \\
\hline
\end{tabular}

Based on the table and chart above, it can be seen that there was an improvement of the teacher's activities from $72.22 \%$ in Cycle 1 to $91.67 \%$ in Cycle 2. So, it could be concluded that there were good improvements in teacher's activities during the teaching and learning process from Cycle 1 to Cycle 2.

In addition, the improvement of students' ability in writing descriptive texts can be seen on the following table:

Table 18 Improvement of Students' Ability in Writing Descriptive Texts

\begin{tabular}{|c|c|c|c|c|c|c|c|}
\hline \multirow{2}{*}{ No. } & \multirow{2}{*}{ Score } & \multicolumn{2}{|c|}{ Pre-Test } & \multicolumn{2}{c|}{ Post-Test 1 } & \multicolumn{2}{c|}{ Post-Test 2 } \\
\cline { 3 - 8 } & & F & \% & F & \% & F & \% \\
\hline 1. & $\geq 75$ & 7 & 24.14 & 13 & 44.83 & 23 & 79.31 \\
\hline 2. & $<75$ & 22 & 75.86 & 16 & 55.17 & 6 & 20.69 \\
\hline \multicolumn{2}{|c|}{ TOTAL } & 29 & 100 & 29 & 100 & 29 & 100 \\
\hline
\end{tabular}

Based on the table and chart above, it meant that almost all of the students were able to pass the Standard Minimum Criteria (75).

\section{CONCLUSION}

Based on the data analysis of the Pre-Test, Post-Test 1, and Post-
Test 2 in the previous chapter, it can be concluded that using Four-Square Writing Method successfully improved the ability of first-year (X.1) students of SMA Negeri 4 Pekanbru in writing descriptive texts. It is proven by the increase of average scores of the students from 68.97 in the pre-test, to 72.77 in the 
post-test 1 and up again to 75.40 in the post-test. This improvement happened because this writing method is appropriate to be applied to the class.

In addition, based on the data analysis of students' observation sheet, It can be concluded that there was a good improvement of students' activities during teaching and learning process from Cycle 1 $(58.05 \%)$ to Cycle 2 (82.18\%). Besides, based on the data analysis of teacher's observation sheet, it also proved that there was a good improvement from teacher's activities in Cycle 1 (72.22\%) to Cycle2 (91.67\%).

There were some factors that influence the increase of the students' writing ability by the first year (X.1) students of SMAN 4 Pekanbaru in writing descriptive texts, such as the students' familiarity with the topic and the students' ability in applying the method that had been taught by the writer. Moreover, the Four-Square Writing Method is not only about increasing writing ability but also helps the students organize their ideas in writing. By using the Four-Square Writing Method, the students are helped to put similar ideas together to create a simple paragraph easier and fun. This method also helps students to plan before writing. In addition, The students are easy to make a line to write the paragraph. According to the result of observation sheets, the students are motivated and interested in writing descriptive text using Four-Square Writing Method. Thus, using the Four-Square Writing Method in writing descriptive texts is successful in improving the students' writing ability.

Based on the data that has been found in this research, there are some suggestions that the writer gives to implement Four-Square Writing Method in the classroom. Firstly, it is suggested that in teaching writing, English teachers might be using the various method of teaching to make the lesson more interesting. Four-Square Writing Method is one method that may use in teaching and improving the students' writing ability. Secondly, the teacher who wants to use Four- 
square Writing Method in the classroom needs to give a clear explanation about what the students will do in each activity. Since FourSquare Writing Method takes much time in writing the outline (using four square organizers) before taking off to the paragraph form and also gathering ideas activity, the English teacher needs to be able to manage the time in applying this method. Thirdly, the English teacher may be able to give motivation to the students to work well in their writing. The English teacher may be able to give positive support and explanation to every student to create their ideas. Fourthly, it would be better for the English teacher to know the topic of text that the students might familiar with or the topic that the students know. The English teacher must also be able to give a brief explanation about the topic if the students do not know about it at all. It is suggested that the topic of the text is something they have known before or close to what they have done in the past. Finally, it is suggested that a reward is given to students with the highest achievement during the teaching and learning process. The reward should be something that can motivate the students to do the best next time.

\section{REFERENCES}

Algaze, Louis, et al. (2005). Improving Persuasive Writing Through the Use of the FourSquare Writing Method. Retrieved: December 20, 2013 from:

http://americanshs.org/Improvi ng+Persuasive+Through + the+Use+of + the + Four+ Square+Writing+Method

Azhar, Fadly., et.al. (2006). Panduan Penulisan dan Pelaksanaan Ujian Skripsi pada Program Studi Pendidikan Bahasa Inggris Jurusan Pendidikan Bahasa dan Seni FKIP - UNRI. Universitas Riau. Pekanbaru.

Bartholamae, Megan, et al. (2010). Bringing Four Square Writing to Life. Retrieved: December 20, 2013 from: http://www.d46.k12.il.us/2011 $\underline{\text { con }}$ ference/pdf/454squarepres.pdf

Bander, Robert .G. (1978). American English Rhetoric. Harcourt College Publishers: United States of America.

Blanchard, Karen and Cicik Kurniawan. (2005). Let's Talk: Grade VIII for Junior High School. Pakar Karya: Bandung. 
Brown. (2001). How to writing process.

Retrieved:

December 20, 2013 from: http://www.nadabs.tripod.com/ gha ith-writing.html

Cohen, A. (1989). Assessing language ability in the classroom (2nd ed). Heinle \& Heinle:Boston

Cooper, Peter.L. (1984). The Assessment of Writing Ability: A Review of Research. Educational Testing Service: New Jersey.

Devitt, Amy. J. (2004). Writing Genre. Southern Illinios University: United States of America.

Gay, L. R. (2000). Educational Research Competence for Analysis and Application. Prentice Hal: USA

Gerrot,L., and P. Wignel. (1995). Making Sense of Functional Grammar. Antepodean Educational Enterprises: Sidney.

Gould,Judith S. and Evan Jay Gould. (1999). Four-Square Writing Method. Retrieved: December 20, 2013 from: http://pasdprofessionaldevelopme nt.wikispaces.com/Four+Square+ Writing.
Gould, J. S., \& Evan, J. (2002). Four Square: The Total Writing Classroom. Teaching and Learning Company: Carthage, IL.

Harmer, Jeremy. (2001). The Practice of English Language Teaching, Third Edition. Pearson Education Limited. England.

Harris, David. P. (1974). Testing English as a Second Language. Mc.Grow Hill: New York.

Hartono. (2011). Statistik untuk Penelitian. Pustaka Pelajar: Yogyakarta.

Hatch, E and Farhady. (1982). Research Design and Statistics for Applied Linguistic. Newbury House Publisher.Inc: London.

Heaton, J.B. (1989). Writing English Language Tests. Longman: London

Herrero, Annabelle Hernández. (2007). Journals: A Tool to Improve Students' Writing Skills. Retrieved: December 20, 2013 